\title{
Formulasi dan evaluasi granul effervescent ekstrak daun binahong (Anredera cordifolia (Tenore) Steen.)
}

\author{
Indah Fortuna Rahmawati, Prasojo Pribadi, Imron Wahyu Hidayat \\ DIII Farmasi, Fakultas Ilmu Kesehatan, Universitas Muhammadiyah Magelang \\ Jl. Mayjend Bambang Soegeng, Mertoyudan, Magelang
}

\begin{abstract}
ABSTRAK
Penelitian ini bertujuan untuk mengetahui granul effervescent ekstrak daun binahong yang diformulasikan telah memenuhi persyaratan dan menentukan formulasi granul effervescent yang terbaik. Penelitian ini merupakan penelitian deskriptif eksperimental dengan pengambilan data dari evaluasi granul effervescent. Untuk membuat sediaan granul effervescent terlebih dahulu dilakukan ekstraksi daun binahong. Ekstrak diperoleh dari metode maserasi menggunakan pelarut etanol 70\%. Formula granul effervescent dibuat sebanyak tiga buah dengan variasi konsentrasi ekstrak F1 7,4\%; F2 14,8\%; dan F3 $22,2 \%$. Granul effervescent daun binahong dibuat dengan menggunakan metode granulasi basah dan dilakukan evaluasi mutu fisik granul meliputi uji organoleptik, kadar air, volume tuang, volume guncang, daya alir, waktu dispersi, dan $\mathrm{pH}$. Hasil penelitian menunjukkan semua granul effervescent ekstrak daun binahong (Anredera cordifolia (Tenore) Steen.) telah memenuhi persyaratan granul yang baik. Dari ketiga formulasi, granul terbaik adalah F3, di mana memiliki nilai terbaik pada pengujian kadar air, uji volume guncang, daya alir, dan $\mathrm{pH}$.
\end{abstract}

Kata kunci : formulasi, evaluasi, granul effervescent, daun binahong

\begin{abstract}
The purpose of this research are to find out whether the formulation of effervescent granules from binahong leaves extract has met the standards for effervescent granules and determine the best formulation of effervescent granules. This research is descriptive experimental with data collection from evaluation of effervescent granules. To be able to make effervescent granules, extraction of binahong leaves must be made first. The extracts resulted from a maseration method with $70 \%$ ethanol. The effervescent granules formulation were made by 3 design based on their concentration F1 7.4\%; F2 $14.8 \%$; and F3 22.2\%. Effervescent granules of binahong leaves extract are prepared by using wet granulation method. Several physical tests were carried out on the results of effervescent granules of binahong leaves, including organoleptic test, moisture content test, pour volume test, volume of shringkage test, flow capacity test, dispersion test, and $\mathrm{pH}$. The test results showed that all the effervescent granules of binahong leaves (Anredera cordifolia (Tenore) Steen.) have met the standard requirements as good granules. The third formula became the best formulation-With the best value in moisture content test, volume of shringkage test, flow capacity test, and $\mathrm{pH}$.
\end{abstract}

Keywords: formulation, evaluation, effervescent granules, binahong leaves 


\section{PENDAHULUAN}

Tanaman binahong (Anredera cordifolia) adalah tanaman obat potensial yang dapat mengatasi berbagai jenis penyakit. Bagian tanaman binahong yang bermanfaat sebagai obat pada umumnya adalah daun (Fitriyah, 2013). Uji farmakologis mendapati tumbuhan ini mampu berperan sebagai antibakterial, anti obesitas, dan antihiperglikemik, antimutagenik, antiviral, antiulser dan antiinflamasi. Analisis fitokimia mengindikasikan daun binahong mengandung saponin, alkaloid, dan flavonoid (Cloridina, 2009 dalam Kurniawan, 2014).

Formulasi yang tepat dalam pengolahan bahan alam menjadi suatu bentuk sediaan yang mudah diterima masyarakat diharapkan dapat meningkatkan kepraktisan dan minat masyarakat dalam mengkonsumsi obat bahan alam. Salah satu upaya untuk meningkatkan efisiensi dan minat masyarakat tersebut adalah dengan membuat dalam bentuk ekstrak dan selanjutnya diformulasikan dalam bentuk sediaan granul effervescent (Anwar, 2010).

Sediaan effervescent merupakan campuran komponen asam dan basa yang bila ditambahkan dengan air akan bereaksi membebaskan karbon dioksida sehingga menghasilkan buih, serta memberikan efek sparkle atau rasa seperti pada minuman bersoda (softdrink). Berdasarkan hal tersebut maka dalam penelitian ini akan dibuat formula granul effervescent dan dilakukan evaluasi mutu fisik agar memenuhi standar granul yang baik sehingga dapat menghasilkan obat yang aman dan efektif.

\section{METODE PENELITIAN}

Penelitian ini merupakan jenis penelitian deskriptif eksperimental. Penelitian ini menggambarkan karakteristik granul effervescent dari formula yng telah dibuat. Penelitian ini dilakukan di Laboratorium Teknologi Farmasi DIII Farmasi Universitas Muhammadiyah Magelang yang dilaksanakan pada bulan Desember 2014.

\section{Bahan}

Daun binahong yang diperoleh dari perkebunan rakyat di Desa Kaponan Kecamatan Tegalrejo.

\section{Jalannya Penelitian \\ Identifikasi / determinasi tumbuhan binahong}

Determinasi tanaman dimaksudkan untuk membuktikan kebenaran sampel yang digunakan berkaitan dengan ciri-ciri makroskopis. Sampel daun yang digunakan berasal dari Desa Kaponan Kecamatan Tegalrejo. Determinasi simplisia daun binahong dilakukan di Laboratorium Biologi Universitas Ahmad Dahlan Yogyakarta.

\section{Pembuatan ekstrak daun binahong}

Pembuatan ekstrak daun binahong dilakukan dengan metode maserasi, menggunakan pelarut etanol $70 \%$. Sampel daun binahong kering kemudian diayak menggunakan ayakan mesh no. 65, kemudian ditimbang lalu diekstraksi menggunakan etanol 70\% (1:5) dan direndam selama 5 hari. Setelah itu diaduk dengan alat maserator selama 1 jam. Ekstrak kemudian disaring menggunakan kertas saring didapat filtrat 1, kemudian residu diekstrak kembali selama 2 hari menggunakan etanol $70 \%$ didapat filtrat 2. Selanjutnya filtrat 1 dan 2 dikumpulkan, diuapkan pada suhu $70{ }^{\circ} \mathrm{C}$ sampai volumenya menjadi $1 / 4$ dari volume awal, dan dilanjutkan sampai menjadi ekstrak kental.

\section{Granulasi basah ekstrak daun binahong}

Sebanyak 16,8 mL ekstrak kental daun binahong digranulasi basah dengan cara penambahan CMC sebanyak 1,2 $\mathrm{g}$ dan pewarna cair sebanyak $1 \mathrm{~mL}$ pada ekstrak kental daun binahong hingga mendapatkan kepadatan yang tepat untuk di granuasi. Padatan selanjutnya diayak dan di panaskan dalam oven selama 3 jam dengan suhu $60{ }^{\circ} \mathrm{C}$. Komponen ini selanjutnya disebut komponen ekstrak daun binahong.

\section{Pembuatan granul effervescent ekstrak daun binahong}

Metode pembuatan granul ini menggunakan metode granulasi basah. Metode granulasi basah mengacu pada Siregar dan Wikarsa (2010) menggunakan metode cairan non reaktif, yaitu dibuat dua campuran secara terpisah antara campuran asam dan campuran basa. Pemisahan ini dilakukan untuk menghindari reaksi dini effervescent. 


\begin{tabular}{llll}
\multicolumn{4}{c}{ Tabel I. Formulasi granul } \\
\multicolumn{1}{c}{ Komponen } & F 1 \% & F 2 \% & \multicolumn{1}{c}{ F 3 \% } \\
\hline Ekstrak & 7,4 & 14,8 & 22,2 \\
Natrium & 48,1 & 45,64 & 43,18 \\
Bikarbonat & & & \\
Asam Tartrat & 25,6 & 23,14 & 20,68 \\
Asam Sitrat & 16,6 & 14,4 & 11,68 \\
Aspartam & 1,4 & 1,4 & 1,4 \\
CMC & 0,9 & 0,9 & 0,9 \\
Essense & q.s & q.s & q.s \\
\hline
\end{tabular}

Komponen ekstrak daun binahong, natrium bikarbonat, asam tartrat, asam sitrat, dan aspartam sesuai Tabel I ditimbang dan diayak dengan ayakan no. 8. Granul ekstrak daun binahong, asam sitrat, asam tartrat, dan aspartam dicampurkan dalam satu wadah dan disemprot dengan larutan essence dalam etanol (1:4) sebanyak $12 \mathrm{~mL}$. Campuran kemudian diayak dengan ayakan no. 8 kemudian granul dikeringkan dalam oven pada suhu $40-50{ }^{\circ} \mathrm{C}$ selama 3 jam. Granul yang sudah kering diayak kembali dengan ayakan no. 10, dan selanjutnya hasil ayakan ini disebut komponen asam. Dalam wadah lain, natrium bikarbonat disemprot dengan essence dalam etanol (1:4) sebanyak 7,2 mL. Campuran tersebut kemudian diayak dengan ayakan no.8, kemudian granul yang didapat dikeringkan dalam oven pada suhu $40{ }^{\circ} \mathrm{C}$ selama $3 \mathrm{jam}$. Granul yang sudah kering diayak kembali dengan ayakan no. 10, selanjutnya hasil ayakan ini disebut komponen basa. Komponen asam dan komponen basa digranulasi dalam sebuah lumpang hingga homogen. Hasilnya ialah granul effervescent ekstrak daun binahong ditimbang sebagai volume awal. Granul effervescent ekstrak daun binahong dikeringkan dengan oven hingga mendapat volume yang tetap selama 7 jam. Sebelum dikemas, untuk menghindari penyerapan kelembaban dari udara, granul effervescent dimasukkan dalam desikator berisi silica gel selama 1 jam. Setelah itu granul dipindahkan ke wadah lalu disegel secara tepat dan rapat.

\section{Evaluasi granul effervescent ekstrak daun binahong}

Granul effervescent ekstrak daun binahong yang dihasilkan kemudian dievaluasi. Evaluasi granul effervescent meliputi:

1. Uji organoleptik, meliputi bentuk, warna, bau dan rasa dari granul yang dihasilkan.

2. Uji kadar air, dilakukan dengan cara granul basah ditimbang kemudian dikeringkan dalam oven hingga diperoleh bobot yang tetap.

3. Uji volume tuang, ditentukan dari ukuran partikel dan bentuk partikel. Sebanyak $150 \mathrm{~g}$ granul dituang kedalam suatu gelas ukur, permukaannya diratakan. Volume yang terbaca $(\mathrm{mL} / \mathrm{g})$ menggambarkan volume tuang (Voight, 1994).

4. Uji volume guncang, dilakukan dengan cara ditimbang 50 gram massa granul tablet dimasukkan dalam gelas ukur $100 \mathrm{~mL}$, lalu diukur volumenya (V1). Berat jenis bulk didapat dari massa dalam gelas ukur diketuk-ketuk sebanyak 500 kali dari ketinggian $2,5 \mathrm{~cm}$ sampai volume tetap (V2). Berat jenis mampat diukur sebagai nilai kompresibilitas (Siregar dan Wikarsa, 2010).

5. Uji daya alir granul yang telah kering dilakukan dengan cara ditimbang sebanyak 25 gram, lalu dimasukkan ke dalam corong yang bagian bawahnya tertutup. Kemudian bagian bawah corong dibuka sehingga granul dapat mengalir di atas meja yang telah dilapisi kertas. Waktu alir granul ditentukan pada saat granul mulai mengalir sampai granul berhenti mengalir menggunakan stopwatch (Lachman, 2008).

6. Uji waktu dispersi, dilakukan dengan cara dimasukkan $100 \mathrm{~mL}$ air dingin dengan suhu $15-25^{\circ} \mathrm{C}$ ke dalam gelas beker $250 \mathrm{~mL}$. Setelah itu dimasukkan satu bungkus granul effervescent $5 \mathrm{~g}$ kedalam air tersebut. Bila granul tersebut terdispersi dalam air dan menyelesaikan reaksinya dalam waktu $<5$ menit menunjukkan sediaan terdispersi sempurna (Siregar dan Wikarsa, 2010).

7. Uji $\mathrm{pH}$ larutan effervescent dilakukan dengan melarutkan effervescent dalam $200 \mathrm{~mL}$ aquadest kemudian $\mathrm{pH}$ diukur dengan alat $\mathrm{pH}$ meter, dan hasil pengukuran dikatakan baik bila $\mathrm{pH}$ larutan effervescent mendekati netral (Rahmah, 2006). 


\section{Analisis Data}

Penelitian ini menggunakan metode analisis deskriptif kualitatif untuk mengetahui apakah granul effervescent ekstrak daun binahong telah memenuhi persyaratan standar granul yang baik dengan pengolahan data menggunakan Microsoft Excel.

\section{HASIL DAN PEMBAHASAN}

\section{Determinasi tanaman}

Determinasi tanaman dimaksudkan untuk membuktikan kebenaran sampel yang digunakan berkaitan dengan ciri-ciri makroskopis dengan mencocokan ciri-ciri tersebut terhadap pustaka. Hasil determinasi yang telah dilakukan di Laboratorium Biologi Universitas Ahmad Dahlan Yogyakarta menerangkan bahwa sampel yang diuji adalah serbuk daun tanaman Anredera cordifolia (Tenore) Steen. 1b, 2b, 3b, 4b, 6b, 7b, 9a, 41b, 42b, 43b, 54b, 59b, 61b, 62b, 63a, 64b,..Familia: Basellaceae $1 \mathrm{~b}, \ldots . . . . . . . . . . . . .$. Genus : anredera $1 \mathrm{a}, \ldots . . . . . . . . . . . .$. Spesies : anredera cordifolia (Tenore.) Steen.

(Steenis, 2005; Tjitrosoepomo, 2007)

\section{Ekstrak daun binahong}

Randemen ekstrak etanol 70\% daun binahong yang dibuat dengan metode maserasi diperoleh hasil sebesar $21,27 \%$. Faktor yang dapat mempengaruhi hasil rendemen antara lain ukuran partikel bahan yang disari; tekstur bahan atau jaringan simplisia; faktor fisika seperti suhu, tekanan, kelarutan, jenis dan polaritas cairan penyari; dan teknik penyarian yang diterapkan. Kendala yang dihadapi saat pembuatan ektrak kental daun binahong ini adalah proses pengeringan daun binahong karena daun mengandung kadar air yang tinggi, sehingga membutuhkan waktu pengeringan lebih lama. Senyawa dalam tanaman mudah rusak oleh sinar matahari langsung, sehingga pada proses pengeringan ditutup dengan kain hitam. Penggunaan pelarut etanol $70 \%$ karena etanol merupakan pelarut yang umum, mampu melarutkan zat baik yang bersifat polar, semipolar, dan nonpolar.

\section{Pembuatan granul effervescent daun binahong}

Granul effervescent pada umumnya diolah dari kombinasi campuran asam sitrat dan asam tartrat, karena penggunaan asam tunggal akan menimbulkan kesukaran dalam pembuatannya. Bila hanya menggunakan asam tartrat saja, maka granul yang dihasilkan akan rapuh, mudah menggumpal dan produk akhirnya akan asin. Bila menggunakan asam sitrat saja akan menghasilkan campuran yang lengket dan sukar digranulasi (Kailaku, 2012).

\section{Evaluasi Granul Effervescent}

\section{a. Uji organoleptik}

Granul effervescent ekstrak daun binahong secara umum berbentuk padatan besar dan memiliki aroma khas seperti zat aktifnya yaitu ekstrak daun binahong. Granul effervescent formula 1 memiliki rasa asam manis dibandingkan dua formula lainnya yang menghasilkan rasa pahit. Hal ini karena tingginya konsentrasi ekstrak daun binahong yang digunakan yaitu $14,8 \%$ dan 22,2\%. Selain mempengaruhi rasa, kandungan ekstrak juga mempengaruhi warna granul, dimana warna granul formula 1 jauh lebih cerah dibandingkan formula 2 dan formula 3. Dari ketiga granul effervescent yang telah diformulasi, yang menghasilkan granul paling baik adalah granul effervescent formula 1 dimana warna granul putih cerah dan memiliki rasa asam manis. Keterangan lebih lengkap dapat dilhat pada Tabel III.

\section{b. Uji kadar air}

Hasil pengukuran kadar air (MC) dengan replikasi sebanyak tiga kali didapatkan rerata pada formula 1,2 , dan 3 yaitu 3,1\%;3,2\%; dan 2,2\%. Granul yang memiliki kadar air paling rendah adalah granul effervescent formula 3 yaitu sebesar 2,2\% (Gambar 1). Hal ini dapat disebabkan oleh jumlah komponen asam dalam formula 3 yang lebih sedikit dibandingkan dengan formula yang lain yaitu sebesar $32,36 \%$. Asam sitrat merupakan salah satu komponen granul effervescent yang masih berbentuk senyawa hidrat (memiliki air kristal). Asam sitrat monohidrat dapat berubah anhidrat dengan pemanasan $74^{\circ} \mathrm{C}$. Pengujian kandungan lembab dilakukan pada suhu $105^{\circ} \mathrm{C}$, sehingga air kristal dalam asam sitrat menguap dan ikut tercatat, menyebabkan kandungan lembab dari granul effervescent meningkat (Anam, 2013). 
Hilangnya air dalam granul effervescent saat pengeringan bertujuan menjamin stabilitas dan pengawetan yang efektif (Palobo, 2012). Semakin kecil kadar air semakin baik kualitas granul yang dihasilkan.

Tabel II. Hasil uji organoleptik

\begin{tabular}{cllll}
\hline \multirow{2}{*}{ Formula } & Warna & Rasa & Bau & Bentuk \\
\hline 1 & Putih & Asam & Khas & Padatan \\
& kekuningan & manis & binahong & besar \\
2 & Kekuningan & Asam & Khas & Padatan \\
& & Pahit & binahong & besar \\
3 & Kuning & Asam & Khas & Padatan \\
& kehijauan & Pahit & binahong & besar \\
\hline
\end{tabular}

\section{c. Uji volume tuang}

Volume tuang menandakan partikel granul memberikan suatu kumpulan yang longar, karena mereka saling bersentuhan antar sisi dan ujungnya sedangkan diantaranya terisi udara (Palobo, 2012). Adanya rongga-rongga partikel yang lebih besar akan menghasilkan nilai porositas yang lebih besar pula. Hasil pengukuran volume tuang dengan replikasi sebanyak tiga kali dari bobot sebanyak 50 gram didapatkan rerata volume pada gelas ukur untuk formula 1 sebesar $89 \mathrm{~mL}$, formula 2 sebesar $90 \mathrm{~mL}$, dan formula 3 sebesar $85 \mathrm{~mL}$ (Gambar 2). Hasil tersebut telah memenuhi persyaratan dimana volume tuang harus lebih besar daripada bobot granul. Semakin besar volume tuang maka akan semakin baik dan mudah mengalir, sehingga apabila dicetak menjadi tablet akan menghasilkan bobot yang seragam. Granul yang memiliki nilai volume tuang paling besar adalah granul effevescent formula 2.

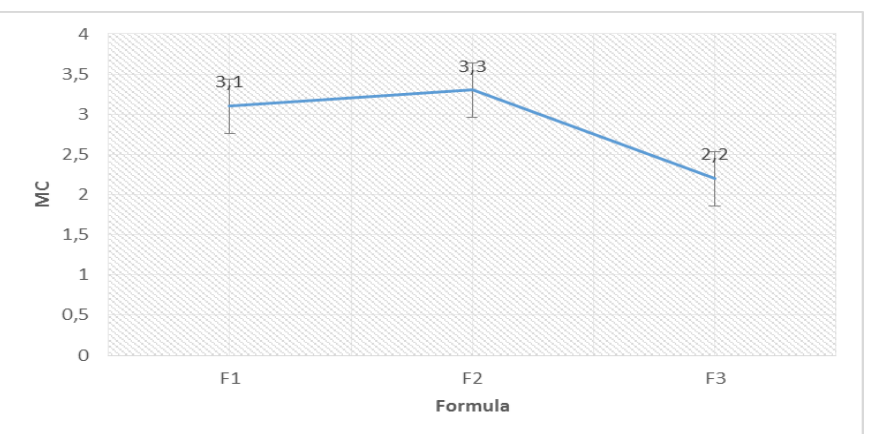

Gambar 1. Kadar air granul effervescent ekstrak daun binahong

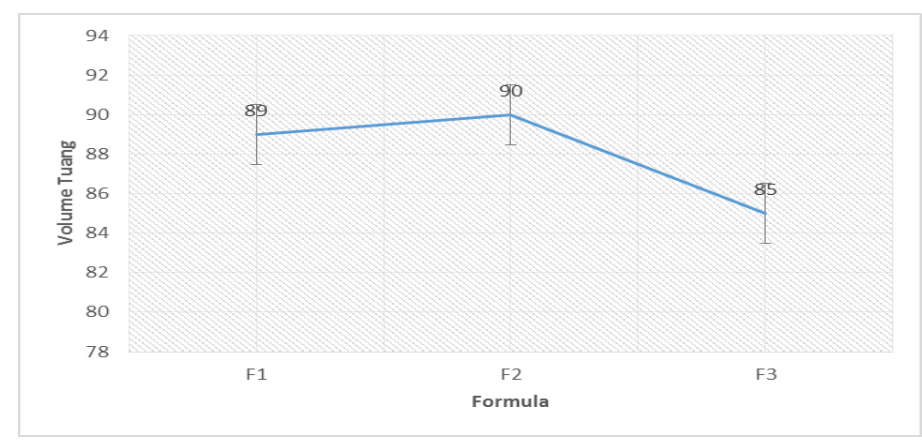

Gambar 2. Volume tuang granul effervescent ekstrak daun binahong

Ukuran partikel dan bentuk partikel mempengaruhi besarnya nilai volume tuang granul. Selain itu kandungan lembab juga dapat mempengaruhi nilai volume tuang. Apabila kandungan lembab granul besar dapat menyebabkan gaya kohesi semakin kuat, apabila gaya semakin kohesi kuat maka granul semakin sukar mengalir. Hal ini dimungkinkan karena proses pembuatan granul effervescent dilakukan di ruangan dengan kelembaban relatif atau RH $>25 \%$ dan suhu $>20^{\circ} \mathrm{C}$. Selain itu sifat asam sitrat yang higroskopis juga berpotensi menyerap uap air di udara (Lestari, 2014). 


\section{d. Uji volume guncang}

Uji volume guncang ini menunjukan granul tersebut akan mencapai kumpulan yang terpadat tanpa perubahan bentuk dari pertikelnya setelah penyusutan. Syarat granul yang baik memiliki nilai penyusutan volume dibawah 20\%. Dari hasil evaluasi dengan replikasi sebanyak tiga kali diperoleh rerata persentase volume guncang pada formula 1,2, dan 3 yaitu 15\%, 14,4\%, dan 8,9\% (Gambar 3). Semakin kecil nilai volume guncang maka semakin baik sifat alirnya. Sifat alir dapat dipengaruhi oleh beberapa faktor antara lain rapat jenis, porositas, bentuk partikel, dan kandungan lembab granul. Dari ketiga formula granul effervescent tersebut yang memiliki nilai volume guncang paling kecil adalah formula 3 .

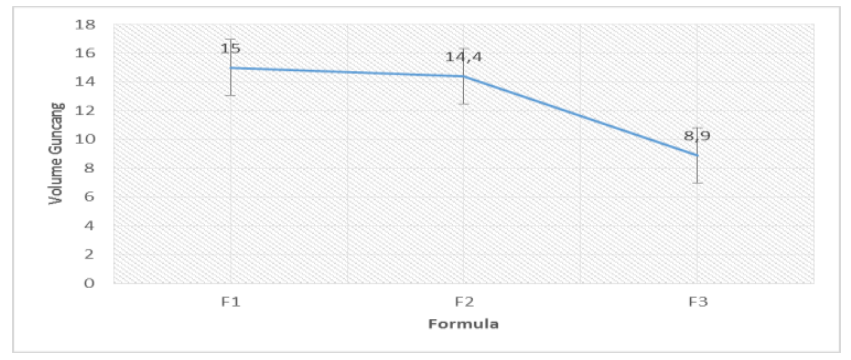

\section{Gambar 3. Volume guncang granul effervescent ekstrak daun binahong}

\section{e. Uji waktu dispersi}

Waktu dispersi atau nama lainnya waktu larut adalah waktu yang dibutuhkan granul untuk larut secara sempurna dalam air. Kelarutan sempurna ditandai dengan berhentinya produksi gas $\mathrm{CO}_{2}$ di dalam air. Kelarutan sangat dipengaruhi oleh adanya bahan aktif dalam formula yang berasal dari tanaman, seperti ekstrak-ekstrak yang memiliki sifat sukar larut dalam air. Hasil waktu dispersi dengan replikasi sebanyak tiga kali didapatkan data granul effervescent formula 2 memiliki rerata waktu larut lebih cepat dibanding formula yang lain yaitu 4 menit 13 detik, sedangkan formula 1 memiliki waktu larut 4 menit 25 detik, dan formula 3 memiliki waktu larut 4 menit 31 detik (Gambar 4). Granul yang baik terdispersi dalam air dan menyelesaikan reaksinya dalam waktu kurang dari 5 menit (Siregar dan Wikarsa, 2010).

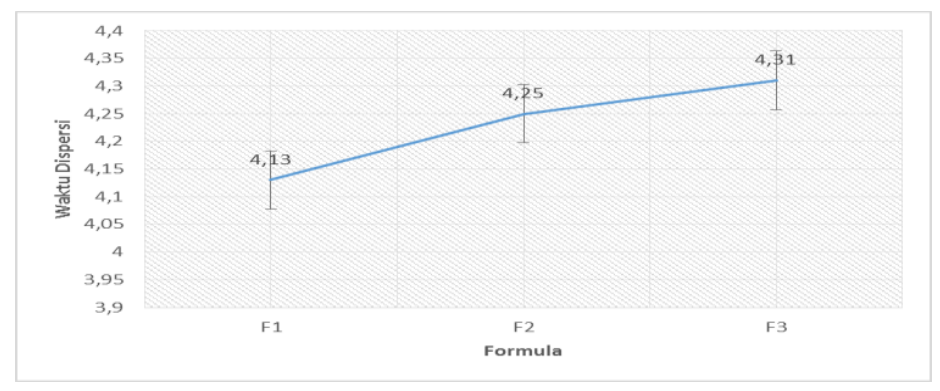

\section{Gambar 4. Waktu dispersi granul effervescent ekstrak daun binahong}

Waktu larut berkaitan dengan nilai porositas (rongga antar partikel) suatu granul, semakin tinggi porositas berarti semakin besar rongga antar partikel, rongga-rongga partikel dapat membantu proses disintegrasi dari granul dimana cairan dapat masuk sehingga dapat mempercepat proses hancurnya granul (Anam, 2013). Hasil uji volume tuang granul formula 2 memiliki nilai yang paling tinggi, hal ini menunjukkan bahwa porositas (rongga antar patikel) granul tersebut besar sehingga mempercepat waktu larut.

Dari pelarutan ketiga formulasi granul semuanya menghasilkan buih yang banyak terutama formula 1. Hal ini karena komponen Natrium bikarbonat dan komponen asam yang digunakan paling banyak dibanding dua formula lainnya. Reaksi komponen basa dan komponen asam dalam granul effervescent daun binahong yang dilarutkan ke dalam air akan menghasilkan buih dari pelepasan gas karbonat dari hasil tersebut. Natrium bikarbonat ketika bereaksi dengan air akan menghasilkan $\mathrm{CO}_{2}$, semakin tinggi konsentrasi natrium biakarbonat dan asam sitrat yang digunakan maka $\mathrm{CO}_{2}$ yang 
dihasilkan semakin banyak. Semakin banyak $\mathrm{CO}_{2}$ yang dihasilkan menunjukkan buih yang dihasilkan semakin banyak (Sandrasari, 2011).

\section{f. Uji daya alir}

Dalam penelitian ini digunakan dua metode untuk mengji waktu alir yaitu metode corong dan metode sudut diam.

1) Metode corong

Hasil pengukuran kecepatan alir dengan replikasi sebanyak tiga kali didapatkan rerata pada formula 1, 2, dan 3 yaitu 5,3 detik; 5,7 detik; dan 4,3 detik (Gambar 5). Ketiga formula tersebut mempunyai sifat alir yang baik, sehingga tidak mengalami kesulitan pada waktu pengempaan tablet, karena waktu alir yang baik untuk pengempaan tablet adalah 4-10 detik untuk 25 gram granul (Stainforth, 1998 dalam Khairi, 2010).

Waktu alir dipengaruhi oleh bentuk, ukuran, porositas, densitas, dan gaya gesek antar partikel granul (Anam, 2013). Sifat alir yang baik akan memudahkan granul memasuki ruang cetakan, sehingga keseragaman bobot dapat terjaga baik (Khairi, 2010). Granul yang memiliki waktu alir paling cepat adalah granul effervescent formula 3. Granul formula 3 memiliki kandungan air paling rendah menyebabkan gaya gesek antar partikel rendah sehingga mempercepat granul untuk mengalir.

2) Metode sudut diam

Hasil pengukuran sudut diam dengan replikasi sebanyak tiga kali didapatkan rerata pada formula 1, 2, dan 3 yaitu $25,46^{\circ} ; 25,89^{\circ}$; dan 25,25 (Gambar 6). Menurut Khairi (2010) sudut diam granul yang baik antara $25^{\circ}-30^{\circ}$. Oleh karena itu semua formula granul effervescent daun binahong menunjukkan sifat alir yang baik. Nilai sudut diam paling kecil yaitu pada granul effervescent formula 3. Hal ini dapat disebabkan karena kandungan air granul formula 3 yang paling rendah. Kandungan lembab yang lebih besar dapat menyebabkan gaya kohesi yang lebih besar pula. Suatu granul yang tidak kohesif akan mengalir baik, menyebar membentuk timbunan yang rendah sehingga membentuk sudut yang lebih kecil (Anam, 2013).

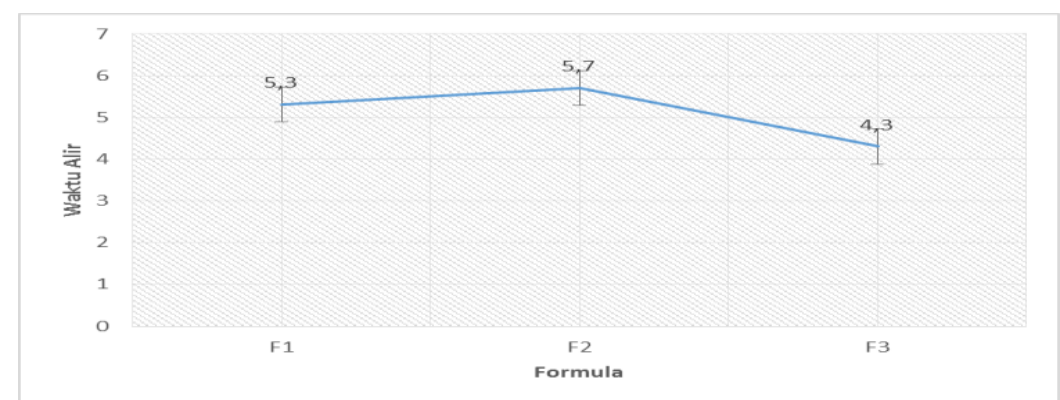

Gambar 5. Waktu alir granul effervescent ekstrak daun binahong

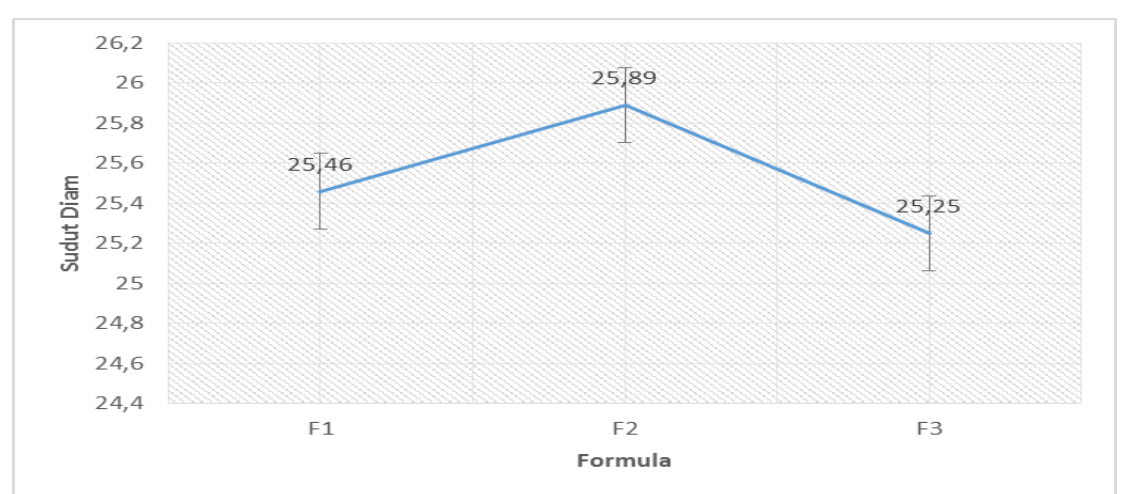

Gambar 6. Sudut diam granul effervescent ekstrak daun binahong

\section{g. Uji pH}

Pengamatan $\mathrm{pH}$ perlu dilakukan karena jika larutan effervescent yang terbentuk terlalu asam dapat mengiritasi lambung, sedangkan jika terlalu basa menimbulkan rasa pahit dan tidak enak. Berdasarkan derajat keasaman, bahan pangan dapat digolongkan ke dalam ketiga kelompok, yaitu (1) bahan pangan 
berasam rendah dengan kisaran $\mathrm{pH} 5,3$ sampai 4,5; (2) bahan pangan berasam sedang dengan kisaran $\mathrm{pH}$ 4,5 sampai 3,7 dan (3) bahan pangan berasam tinggi dengan nilai $\mathrm{pH}$ dibawah 3,7 (Kailaku, 2012).

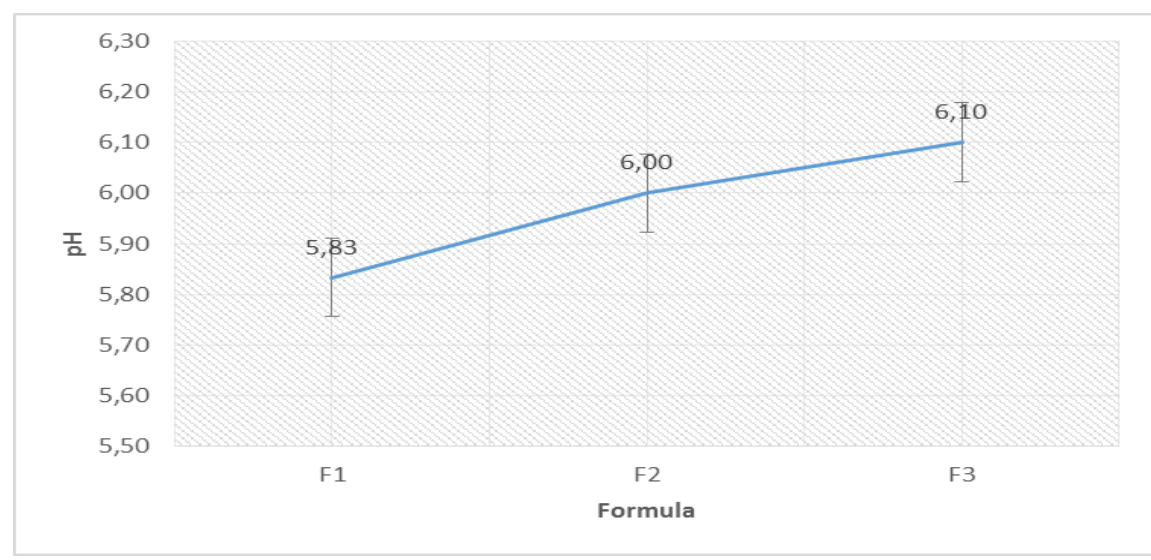

Gambar 7. pH granul effervescent esktrak daun binahong

Hasil pengukuran $\mathrm{pH}$ dengan replikasi sebanyak tiga kali didapatkan rerata pada formula 1, 2, dan 3 yaitu Diketahui bahwa rata-rata $\mathrm{pH}$ pada ketiga formula berkisar antara 5,8 sampai 6,1. $\mathrm{pH}$ larutan effervescent dikatakan baik jika $\mathrm{pH}$ mendekati netral yakni 6-7. Dari data yang telah diperoleh dapat dikatakan bahwa ketiga formula granul memiliki nilai $\mathrm{pH}$ larutan yang telah memenuhi syarat dan termasuk golongan bahan pangan berasam rendah. Salah satu faktor yang dapat mempengaruhi keasaman $\mathrm{pH}$ adalah pembentukan $\mathrm{CO}_{2}$ pada saat terjadi reaksi effervescing dalam air yang sebagian akan larut membentuk asam karbonat. Asam karbonat ini kemudian mengurai menghasilkan ion $\mathrm{H}^{+}$dalam larutan yang menyebabkan keasaman pada larutan (Sandrasari, 2011). Nilai $\mathrm{pH}$ paling baik adalah $\mathrm{pH}$ granul effervescent formula 3 . Formula 3 memiliki $\mathrm{pH}$ yang rendah atau mendekati netral karena komponen asam yang digunakan paling sedikit dibanding dua formula yang lain yaitu sebesar $32,36 \%$.

\section{KESIMPULAN}

Dari hasil penelitian formulasi dan evaluasi granul effervescent ekstrak daun binahong (Anredera cordifolia (Tenore) Steen) dapat diambil kesimpulan bahwa granul effervescent ekstrak daun binahong yang diformulasikan ketiganya telah memenuhi syarat standar granul yang baik. Granul terbaik adalah formula 3 di mana memiliki nilai terbaik pada pengujian kadar air, uji volume guncang, uji waktu alir, dan uji $\mathrm{pH}$.

\section{DAFTAR PUSTAKA}

Anam, C., Kawiji, dan Setiawan, R.D., 2013, Kajian karakteristik fisik dan sensori serta aktivitas antioksidan dari granul effervescent buah beet (Beta Vulgaris) dengan perbedaan metode granulasi dan kombinasi sumber asam, Jurnal Teknosains Pangan, 2(2): 21-28.

Anwar, K., 2010, formulasi sediaan tablet effervescent dari ekstrak kunyit (Curcuma domestica Val.) dengan variasi jumlah asam sitrat - asam tartrat sebagai sumber asam, Jurnal Sains dan Terapan Kimia, 4(2): 168-178.

Fitriyah, N., Purwa, M., dan Alfiyanto, M.A., 2013, Obat herbal antibakteri, ala tanaman binahong, Jurnal KesMaDaSka, 116-122.

Kailaku, S.I., Jayeng, S., dan Hernani, 2012, Formulasi granul effervesen kaya antioksidan dari ekstrak daun gambir, Jurnal Pascapanen, 9(1): 27-34.

Khairi, N., Latifah, R., dan Marianti, A., 2010, studi formulasi tablet efervesen ekstrak angkak dengan variasi konsentrasi bahan pengikat polivinilpirilidon sebagai sediaan terapi suportif demam berdarah, Tesis, Program Pascasarjana Farmasi, UNHAS.

Kurniawan, B.N, Carolina, Sukohar, A., 2014, Uji efektivitas antiinflamasi ekstrak daun binahong (Anredera cordifolia (Ten.) Steenis) pada tikus jantan galur Sparague Dawley yang diinduksi karagenin, Jurnal Medical Faculty of Lampung, 4(8): 151-157.

Lachman, L., Lieberman, H.A., Schwartz, J.B., 2008, Teori dan Praktek Farmasi Industri, Vol 1, Marcel Dekker Inc, New York. 
Lestari, P.M, Radjab, N.S, dan Octaviani, A., 2014, Formulasi dan evaluasi fisik granul effervescent sari buah naga (Hylocereus Undatus), Farmasains, 2(4): 182-185.

Palobo, F.N., Yamelan, P.V.Y., dan Yudistira, A., 2012, Formulasi granul effervescent ekstrak dauk leilem (Clerodendrum minahassae L), Jurnal Pharmacon, 1(2): 64-71.

Rahmah, S., 2006, Formulasi granul effervescent campuran ekstrak herba Seledri (Avium graveolens) dan ekstrak daun tempuyung (Sounchus avensis L.), Skripsi, Depok, Farmasi UI.

Sandrasari, D.A., dan Abidin, Z., 2011, Penentuan konsentrasi natrium bikarbonat dan asam sitrat pada pembuatan serbuk minuman anggur berkarbonasi (Effervescent), Jurnal Teknologi Industri Pertanian, 21 (2), 113-117.

Siregar, C.J.P. dan Wikarsa, S., 2010, Teknologi Farmasi Sediaan Tablet Dasar-Dasar Praktis, Buku Kedokteran EGC, Jakarta.

Tjitrosoepomo, G., 1988, Taksonomi Tumbuhan Spermatophyta, Gadjah Mada University Press, Yogyakarta,152-155.

Voight, R., 1994, Pelajaran Teknologi Farmasi, (Terjemahan), Gadjah Mada University Press, Yogyakarta.

Van Steenis, C.G.G.J., 2003, Flora, Pradya Paramita, Jakarta, 233-236. 
